\title{
ANALISIS PENANGANAN SAMPAH OLEH IBU RUMAH TANGGA DI PULAU SAPULI KABUPATEN PANGKEP
}

\author{
Erlani, Abdur Rivai, Juherah \\ Jurusan Kesehatan Lingkungan \\ e-mail : erlanirappe66@gmail.com
}

\begin{abstract}
ABSTRAK
Banyaknya sampah merupakan tujuan penelitian mengetahui kepemilikan wadah sampah, mengetahui pemilahan, pengumpulan, pengangkutan, dan pengolahan sampah, dan mengetahui faktor-faktor yang mempengaruhi ibu rumah tangga dalam penanganan sampah di Pulau Sapuli. Desain atau jenis yang digunakan dalam penelitian ini adalah deskriptif dengan analisis kualitatif dan kuantitatif, yaitu untuk mengetahui faktor-faktor yang mempengaruhi ibu rumah tangga dalam penanganan sampah di pulau Sapuli Kabupaten Pangkep. Hasil penelitian diperoleh wadah atau sarana untuk penanganan sampah yang dimiliki ibu rumah tangga berjumlah $43(31 \%)$. Penanganan sampah yang meliputi pemilahan, pengumpulan, pengangkutan, pengolahan, dan pemrosesan akhir sampah, diperoleh data sebanyak 90 (65,69\%) responden tidak menangani sampahnya. Faktor-faktor yang mempengaruhi penanganan sampah oleh ibu rumah tangga meliputi; penyuluhan, sarana prasarana, peran serta masyarakat, perilaku (pengetahuan, sikap, dan tindakan). Uji regresi logistik dengan korelasi bersama dengan variabel lainnya terhadap penanganan sampah (korelasi majemuk) dengan teknik Chi-Square didapat nilai Chi-Square 70,600 dengan nilai Sig $0.000<$ 0.05 berarti secara bersama-sama penyuluhan, peran serta masyarakat, sarana prasarana, pengetahuan, sikap, dan tindakan berhubungan dengan penanganan sampah. Adapun koefisien determinan regresi logistik yakni 0,556 sehingga dapat dikatakan kontribusi variabel penyuluhan, peran serta masyarakat, sarana prasarana, pengetahuan, sikap, dan tindakan terhadap penanganan sampah adalah sebesar $56 \%$.
\end{abstract}

Kata Kunci : Penanganan sampah, ibu rumah tangga

\section{PENDAHULUAN}

Permasalahan sampah bukan lagi sekedar masalah kebersihan dan lingkungan saja, tetapi sudah menjadi masalah sosial yang berpotensi menimbulkan konflik. Lebih parah lagi, hampir semua kota di Indonesia baik kota besar maupun kota kecil, belum memiliki sistem penanganan sampah yang baik (Damanhuri, 2005:1-1). Umumnya kota di Indonesia memiliki manajemen sampah yang sama yaitu metode kumpul - angkut - buang Sebuah metode manajemen persampahan klasik yang akhirnya berubah menjadi praktek pembuangan sampah secara sembarangan tanpa mengikuti ketentuan teknis di lokasi yang sudah ditentukan.

Seiring dengan pesatnya laju pertambahan penduduk di Pulau Sapuli ancaman terhadap sumber daya alam dan ekosistem semakin meningkat pula. Salah satu ancaman serius terhadap keutuhan sumber daya alam dan ekosistem dan gangguan estetika adalah keberadaan sampah yang dibuang begitu saja ke lingkungan pesisir/laut tersebut. Kondisi ini didukung pula oleh perilaku manusia yang memungkinkan terjadinya peningkatan produksi sampah yang mencapai tahap dimana produksi sampah lebih dominan daripada kemampuan untuk memusnahkan sampah yang dihasilkan tersebut. Dengan adanya fakta tersebut maka perlu disadari bahwa partisipasi masyarakat memegang peranan penting dalam upaya pemecahan masalah kesehatan khususnya sampah karena sebagian masalah tersebut muncul akibat perilaku masyarakat itu sendiri.

Permasalahan sampah erat sekali kaitannya dengan perilaku masyarakat dalam pengelolaan atau penanganan sampah, sebab masyarakatlah yang merupakan sumber utama sampah itu sendiri. Mengatasi permasalahan sampah dari sumbernya akan menjadikan permasalahan sampah menjadi lebih sederhana. Di tengah kesulitan dan keterbatasan pemerintah dalam hal penyediaan fasilitas dan sumber daya manusia untuk pengelolaan sampah maka peran masyarakat khsusunya ibu rumah tangga dalam pengelolaan sampah menjadi aspek yang sangat penting.

Penanganan sampah berbedabeda disetiap daerah, dan begitu juga dengan perilaku masyarakatnya 
terhadap sampah yang dihasilkannya. Suatu daerah yang berhasil mengelola kebersihan dari sampah dan lingkungannya dengan baik diberi anugrah dari pemerintah atau pihak lain yang sudah dikenal luas oleh masyarakat yaitu Penghargaan Adipura.

Berdasarkan uraian diatas peneliti merasa perlu meneliti tentang penanganan sampah oleh ibu rumah tangga dengan memperhatikan faktor perilaku masyarakat, sarana dan parasarana, peran serta masyarakat, dan sosialisai penyuluhan.

\section{METODE PENELITIAN}

Desain atau jenis yang digunakan dalam penelitian ini adalah deskriptif dengan analisis kualitatif dan kuantitatif, yaitu untuk mengetahui faktor-faktor yang mempengaruhi ibu rumah tangga dalam penanganan sampah di pulau Sapuli Kabupaten Pangkep. Lokasi penelitian di Pulau sapuli Kabupaten Pangkajene, dan Kepulauan. Populasi dalam penelitian adalah seluruh ibu rumah tangga di pulau Sapuli Kabupaten Pangkep dengan jumlah KK 137. Jumlah sampel dalam penelitian ini adalah total sampling terhadap semua ibu rumah tangga yang ada di pulau Sapuli Kabupaten Pangkep. Teknik pengumpulan data adalah dengan menggunakan cara : data primer diperoleh melalui kuesioner, observasi/pengamatan dan wawancara langsung terhadap ibu-ibu rumah tangga dan data sekunder merupakan data yang diperoleh melalui referensi hasil penelitian sebelumnya, laporan dari media massa, internet, beberapa buku dan literatur - literatur lain yang berkaitan dengan penelitian. Data yang telah dikumpulkan menggunakan kuesioner diolah secara kuantitatif dengan menggunakan SPSS. Pengolahan data kuantitatif dilakukan dengan menggunakan Uji statististik Regresi logistik. Data disajikan dalam bentuk tabel, dianalisis secara kuantitatif, dan dilakukan pula analisis data kualitatif sebagai pendukung kuantitatif. Data kualitatif akan diolah melalui tiga tahap analisis data kualitatif, yaitu reduksi data, penyajian data dan penarikan kesimpulan. Analisis data kualitatif diuraikan secara deskriptif sebagai pendukung data kuantitatif.

\section{HASIL}

Berdasarkan tabel 5.9 bahwa pengujian secara sendiri-sendiri ternyata hanya sarana parsarana, dan sikap yang signifikan karena nilai Sig 0,003 dan $0,000<0,05$. Sedangkan penyuluhan, peran serta masyarakat, pengetahuan dan tindakan nilai Sig > 0,05 artinya penyuluhan, peran serta masyarakat, pengetahuan dan tindakan tidak punya pengaruh yang signifikan terhadap penanganan sampah oleh ibu rumah tangga. Selanjutnya korelasi bersama dengan variabel lainnya terhadap penanganan sampah (korelasi majemuk) dengan teknik Chi-Square (uji regresi logistik terlampir) didapat nilai Chi-Square 70,600 dengan nilai Sig $0.000<0.05$ berarti secara bersamasama penyuluhan, peran serta masyarakat, sarana prasarana, pengetahuan, sikap, dan tindakan berhubungan dengan penanganan sampah. Adapun koefisien determinan regresi logistik (terlampir) yakni 0,556 sehingga dapat dikatakan kontribusi variabel penyuluhan, peran serta masyarakat, sarana prasarana, pengetahuan, sikap, dan tindakan terhadap penanganan sampah adalah sebesar $56 \%$.

\section{PEMBAHASAN}

Sebanyak 90 (65,69\%) responden tidak menangani sampahnya, sedangka penanganan sampah dengan cara pengumpulan atau melakukan pengambilan dan pemindahan sampah dari sumber sampah sampai ketempat penampungan sementara, hanya ada beberapa ibu rumh tangga. Kegiatan penanganannya tersebut ternyata hanya sebatas sampai pada tahap penampungan sementara, dan tahap selanjutnya langsung dibuang begitu saja ke perairan pantai/laut. Masyarakat di Pulau Sapuli yang sudah terbiasa dengan penanganan sampah tidak sebagaimana mestinya, kemudian tidak didukung dengan fasilitas untuk penanganan tersebut. Ibu-ibu rumah 
tangga sebagai responden yang paling utama bersentuhan dengan produksi sampah dengan tingkat pendidikannya hanya SD tentu memungkinkan kurang pengetahuannya tentang mengelola sampah yang baik dan memenuhi syarat.

Walupun ibu rumah tangga di Pulau Sapuli telah diberikan penyuluhan ternyata tidak berbanding lurus dengan aktifitasnya untuk menangani sampahnya, karena mereka tidak memahaminya dengan baik dari materi penyuluhan yang disampaikan. Mengerti dan memahami materi penyuluhan, tetapi belum tentu akan dapat mengaplikasikannya, karena berkaitan dengan pola perilaku yang memerlukan proses perubahannya panjang ke arah yang positif. Tujuan penyuluhan harapannya adalah agar pola perilaku masyarakat berubah dari kebiasaan tidak menangani sampah menjadi terbiasa untuk selalu menangani sampah dengan baik. Adapun tujuan jangka pendeknya, terciptanya suatu masyarakat yang mengerti, memahami akan masalah kebersihan.

Berdasarkan hasil uji regresi logistik dengan korelasi bersama dengan variabel lainnya terhadap penanganan sampah (korelasi majemuk) dengan teknik Chi-Square (uji regresi logistik terlampir) didapat nilai Chi-Square 70,600 dengan nilai Sig $0.000<0.05$ berarti secara bersama-sama penyuluhan berhubungan dengan penanganan sampah. Sedangan pengujian secara sendiri-sendiri ternyata penyuluhan nilai $\mathrm{Sig}>0,05$ artinya penyuluhan tidak punya pengaruh yang signifikan terhadap penanganan sampah oleh ibu rumah tangga. Adapun koefisien determinan regresi logistik (terlampir) yakni 0,556 sehingga dapat dikatakan kontribusi variabel penyuluhan terhadap penanganan sampah adalah sebesar $56 \%$.

Secara umum peran serta masyarakat di Pulau Sapuli dalam aktifitas penanganan persampahan di lingkungannya masih belum optimal. Sebenarnya peran serta masyarakat dapat dimulai dari skala individual rumah tangga yaitu dengan mereduksi timbulan sampah rumah tangga. Teknik reduksi sampah ini dikenal dengan nama metoda 3R (reduce, reuse, recycle). Sebagai contoh penerapan metoda $3 \mathrm{R}$ dalam kehidupan sehari-hari, misalnya : memilih produk yang kemasannya cenderung menimbulkan sampah paling kecil/sedikit, menggunakan kembali botol-botol tempat minyak atau bahan makanan, dan memisahkan sampah basah ( organik, sampah dapur, sayur, sisa makanan ) dengan sampah kering (anorganik, kertas, plastik, botol ), untuk diolah kembali.

Berdasarkan hasil uji regresi logistik diperoleh variabel sarana prasarana signifikan, karena nilainya $0,003<0,05$ artinya bahwa faktor sarana dan prasarana punya pengaruh yang signifikan tehadap penanganan sampah oleh ibu rumah tangga. Selanjutnya korelasi bersama dengan variabel lainnya terhadap penanganan sampah (korelasi majemuk) dengan teknik Chi-Square didapat nilai ChiSquare 70,600 dengan nilai Sig $0.000<$ 0.05 berarti secara bersama-sama penyuluhan, peran serta masyarakat, sarana prasarana, pengetahuan, sikap, dan tindakan berhubungan dengan penanganan sampah. Sedangkan koefisien determinan regresi logistik (terlampir) yakni 0,556 sehingga dapat dikatakan kontribusi variabel sarana prasarana terhadap penanganan sampah adalah sebesar $56 \%$. Sebagaimana halnya di Pulau Sapuli tidak dapat juga berjalan penanganan sampahnya, karena fasilitas sarana prasarana pendukungnya tidak tersedia dan memang belum mendapat pelayanan dari Dinas Kebersihan Kabupaten Pangkep. Interpretasi regresi logistik dengan korelasi bersama dengan variabel lainnya terhadap penanganan sampah (korelasi majemuk) dengan teknik Chi-Square (uji regresi logistik terlampir) didapat nilai Chi-Square 70,600 dengan nilai Sig $0.000<0.05$ berarti secara bersama-sama sikap ibu rumah tangga berhubungan dengan penanganan sampah. Sedangkan koefisien determinan regresi logistik 
(terlampir) yakni 0,556 sehingga dapat dikatakan kontribusi variabel pengetahuan terhadap penanganan sampah adalah sebesar 56\%. Begitu juga dengan pengujian secara sendirisendiri ternyata sikap signifikan karena nilai Sig $0,000<0,05$, artinya sikap punya pengaruh yang signifikan terhadap penanganan sampah oleh ibu rumah tangga. Hasil penelitian tentang perilaku (sikap) tersebut sejalan Sikap itu masih merupakan reaksi tertutup, bukan merupakan reaksi terbuka atau tingkah laku yang terbuka. Sikap adalah komponen yang mendahului tindakan atau praktik terbuka, tetapi tidak otomatis bahwa sikap postif menyebabkan seseorang bertindak positif. Sebagaimana halnya ibu rumah tangga di Pulau Sapuli mereka bersikap baik atau setuju untuk menangani sampah, akan tetapi praktik penanganannya mayoritas ibu rumah tangga tidak melaksanakannya.

Adapun tindakan penanganan sampah yang dilakukan melalui pengumpulan dengan menggunakan kantong plastik dan wadah lainnya yang tidak memenuhi syarat hanya ada beberapa ibu rumah tangga yaitu sbesar 5,11\%. Data tersebut menunjukkan bahwa ibu-ibu rumah tangga di Pulau Sapuli praktik menangani sampahnya sendiri tidak dijalankan dengan penuh rasa tanggungjawab. Seharusnya ibu rumah tangga yang menghasilkan sampah senantiasa dapat melakukan praktik menangani sampahnya secara otomatis, tanpa menunggu perintah dari petugas.

Berdasarkan hasil penelitian Ayu

Fitriana, dkk (2011) bahwa variabel tindakan responden tentang pengelolaan sampah di Desa Bludru Kidul RW 11 Kecamatan Sidoarjo dari 62 responden didapatkan hasil persentase sebesar $87,3 \%$ kategori nilai kurang. Selanjutnya Hasil penelitian Agus Ramon (2015) bahwa mayarakat Kota Bengkulu tidak melakukan tindakan penanganan sampah dengan baik dan benar (seperti pemilahan, pengumpulan, pengangkutan, pengolahan, pemerosesan akhir). Mereka hanya melakukan pengumpulan sampah di sebuah wadah seperti kantong plastik. Hasil penelitian tersebut sesuai juga dengan peneliti peroleh, karena dari 137 responden ibu rumah tangga tindakannya terhadap penanganan sampah juga kategori kurang dengan persentase $94,89 \%$. Interpretasi regresi logistik dengan korelasi bersama dengan variabel lainnya terhadap penanganan sampah (korelasi majemuk) dengan teknik Chi-Square (uji regresi logistik terlampir) didapat nilai Chi-Square 70,600 dengan nilai Sig $0.000<0.05$ berarti secara bersamasama perilaku (tindakan) ibu rumah tangga berhubungan dengan penanganan sampah. Sedangkan koefisien determinan regresi logistik yakni 0,556 sehingga dapat dikatakan kontribusi variabel tindakan terhadap penanganan sampah adalah sebesar $56 \%$.

\section{KESIMPULAN DAN SARAN}

Beradasarkan uji regresi logistik dengan korelasi bersama dengan variabel lainnya terhadap penanganan sampah (korelasi majemuk) dengan teknik ChiSquare didapat nilai Chi-Square 70,600 dengan nilai Sig $0.000<0.05$ berarti secara bersama-sama penyuluhan, peran serta masyarakat, sarana prasarana, pengetahuan, sikap, dan tindakan berhubungan dengan penanganan sampah. Adapun koefisien determinan regresi logistik yakni 0,556 sehingga dapat dikatakan kontribusi variabel penyuluhan, peran serta masyarakat, sarana prasarana, pengetahuan, sikap, dan tindakan terhadap penanganan sampah adalah sebesar $56 \%$. Meningkatkan peran serta masyarakat dalam pelaksanaan tindakan nyata program kebersihan lingkungan di Pulau Sapuli.

\section{DAFTAR PUSTAKA}

Adi Heru Sutomo, 2013. Kesehatan Lingkungan untuk Keperawatan. Yogyakarta: Fitramaya.

Anwar Recca, 2014. Buku Putih Sanitasi Kabupaten Pangkajene Dan Kepulauan Provinsi Sulawesi Selatan. Pangkajene : Program 
Percepatan Pembangunan Sanitasi. Permukiman(PPSP). (http://ppsp.nawasis.infosanitasi-pokja .18 januari 2017), diakses, 19 Juli 2017.

Ayu Fitriana, 2011. Perilaku Ibu Rumah Tangga Dalam Pengelolaan Sampah Di Desa Bluru Kidul Rw 11 Kecamatan Sidoarjo, Jurnal Promkes, Vol. 1, No. 2 Desember 2013: 132-137

Cecep Dani Sucipto, 2012. Teknologi Pengolahan Daur Ulang Sampah.Cetakan Pertama Gosyen Publishing Yogyakarta.

Rehito Traro Hiro Karo Manik ,dkk, 2015. Sistem pengelolaan Samapah di Pulau Bunaken, (online)

http://ejournal.unsrat.ac.id/index. php/spasial/article/, diakses 4 Mei 2017

Reni Elviza, 2013. Perilaku Masyarakat Dalam Pengelolaan Sampah
Rumah Tangga di Kelurahan Tanjung Rhu Kecamatan Lima Puluh Kota Pekanbaru,(online) respiratory.unri.ac.id ; diakses 13 Oktober 2013

Republik Indonesia. 2008. Undang Undang RI No 18 Pengelolaan Sampah.

Republik Indonesia. 2014. UU RI No 1 Pengelolaan Wilayah Pesisir Dan Pulau-Pulau Kecil.

Sarudji, D. 2006. Kesehatan Lingkungan. Media IImu. Surabaya.

Soekidjo Notoatmodjo, 2003. IImu Kesehatan Masyarakat PrinsipPrinsip Dasar. Jakarta: Rineka Cipta.

Perilaku Kesehatan Jakarta :Rineka Cipta

UU Nomor 18 Tahun 2008 Pengelolaan Sampah Perkotaan. 
Lampiran :

Tabel 1 Distribusi Pengetahuan Responden Terhadap Penanganan Sampah di Pulau Sapuli Kabupaten Pangkep 2017

\begin{tabular}{|c|c|c|c|}
\hline \multirow{2}{*}{ No } & \multirow{2}{*}{$\begin{array}{l}\text { Tingkat Pengetahuan } \\
\text { Responden }\end{array}$} & \multicolumn{2}{|c|}{ Jumlah } \\
\hline & & $\mathbf{N}$ & (\%) \\
\hline 1 & Tinggi & 1 & 1 \\
\hline 2 & Sedang & 4 & 3 \\
\hline 3 & Rendah & 132 & 96 \\
\hline & Jumlah & 137 & 100 \\
\hline
\end{tabular}

Tabel 2 Distribusi Sikap Responden Terhadap Penanganan Sampah di Pulau Sapuli Kabupaten Pangkep 2017

\begin{tabular}{clcc}
\hline \multirow{2}{*}{ No } & \multirow{2}{*}{ Sikap Responden } & \multicolumn{2}{c}{ Jumlah } \\
\cline { 3 - 4 } & Sangat baik & - & $(\%)$ \\
\hline 2 & Baik & 72 & - \\
3 & Cukup & 65 & 52,55 \\
4 & Kurang baik & - & 47,45 \\
\hline 5 & Sangat buruk & - & - \\
\hline & Jumlah & 137 & - \\
\hline
\end{tabular}

Tabel 3 Distribusi Tindakan Responden Terhadap Penanganan Sampah di Pulau Sapuli kabupaten Pangkep 2017

\begin{tabular}{|c|c|c|c|}
\hline \multirow{2}{*}{ No } & \multirow{2}{*}{ Tindakan Responden } & \multicolumn{2}{|c|}{ Jumlah } \\
\hline & & $\mathbf{N}$ & (\%) \\
\hline 1 & & 7 & 5,11 \\
\hline 2 & $\begin{array}{l}\text { Balk } \\
\text { Kurang baik }\end{array}$ & 130 & 94,89 \\
\hline & Jumlah & 137 & 100 \\
\hline
\end{tabular}

Tabel 4 Pengaruh Penyuluhan, Peran Serta Masyarakat, Sarana Prasarana, Perilaku Terhadap Variabel Penanganan Sampah

\begin{tabular}{lcrcccc}
\hline & B & S.E. & Wald & Df & Sig & Exp (B) \\
\hline Penyuluhan & $-1,960$ & 2,068 &, 898 & 1 &, 343 &, 141 \\
Peran Serta Masyarakat & 1,972 & 1,085 & 3,300 & 1 &, 069 & 7,183 \\
Sarana Prasarana & 1,878 &, 629 & 8,930 & 1 &, 003 & 6,542 \\
Pengetahuan &, 939 & 1,370 &, 470 & 1 &, 493 & 2,557 \\
Sikap & 3,600 &, 713 & 25,492 & 1 &, 000 & 36,582 \\
Tindakan & 1,510 & 1,276 & 1,401 & 1 &, 237 & 4,529 \\
\hline
\end{tabular}

